\title{
Giant intramuscular infiltrating fibrolipoma of the right leg with common peroneal nerve neuropathy
}

\author{
Sanjay K. Giri, ${ }^{1}$ Dipun Mishra, ${ }^{2}$ Mantu Jain $\odot,{ }^{2}$ Suvnedu Purkait ${ }^{3}$
}

${ }^{1}$ Burns and Plastic Surgey, AllMS Bhubaneswar, Bhubaneswar, Odisha, India

${ }^{2}$ Orthopaedics, AllMS

Bhubaneswar, Bhubaneswar, Odisha, India

${ }^{3}$ Pathology and Lab Medicine, AllMS Bhubaneswar,

Bhubaneswar, Odisha, India

\section{Correspondence to}

Dr Mantu Jain;

montu_jn@yahoo.com

Accepted 27 July 2021

Check for updates

(c) BMJ Publishing Group Limited 2021. No commercial re-use. See rights and permissions. Published by BMJ.

To cite: K. Giri S, Mishra D, Jain $\mathrm{M}$, et al. BMJ Case Rep 2021;14:e244852. doi:10.1136/bcr-2021244852

\section{DESCRIPTION}

Lipomas are benign fatty tumours composed of mature adipocytes that are ubiquitous in their presence. When fibrous septa are present, these are called fibrolipoma. ${ }^{1}$ Usually located subdermally, sometimes they may be subfascial. ${ }^{2}{ }^{3}$ These are further classified as parosteal, interosseous, intramuscular, intermuscular and visceral based on a precise location. ${ }^{45}$ Both intramuscular and intermuscular lipomas are of the infiltrating variety as they are poorly circumscribed. ${ }^{6}$ Fibrolipoma is a variant of lipomas that are seldom seen in the trunk and anterior abdominal wall. ${ }^{1}$ Fibrolipomas of the extremities, particularly the lower one, are rare, with only a few reports in the literature. ${ }^{7-10}$ Here, we present a case of a giant fibrolipoma in the leg that caused common peroneal nerve neuropathy.

A 52-year-old woman presented to our outpatient department with report of painless foot drop for $1 \frac{1 / 2}{2}$ ears associated with a swelling over the anterolateral aspect of her right proximal leg for the past year. The swelling was insidious, gradually progressive in size, measuring about $5 \times 6 \mathrm{~cm}$, geographical in shape with slipping margin, non-tender and located over the anterolateral aspect of the leg about $2 \mathrm{~cm}$ below the knee joint (figure 1A,B). The overlying skin was healthy without any puckering, scar or sinus There was the weakness of ankle dorsiflexion and eversion (2/5) and altered sensation $(1 / 2)$ over the anterolateral aspect of the leg. The posterior tibial artery and dorsalis pedis artery were well palpable. She was not a known case of diabetes or hypertension or any other comorbidity.

The plain radiographs of the right leg and knee were unremarkable. Ultrasound displayed a large mass of markedly homogeneous echotexture without any vascularity. A MRI revealed a large well-defined intramuscular lobulated focal lesion $(74 \times 53 \times 247 \mathrm{~mm})$ in the anterolateral aspect of the upper two-third of the leg involving peroneal, tibialis anterior and extensor digitorum muscles abutting the fibula. Multiple hypointense strands were also seen. The cortical margins of the tibia and fibula were preserved with no evidence of invasion, but the neurovascular bundle was pushed to one side (figure 1C,D). Nerve conduction studies were performed, which revealed common peroneal neuropathy. The MRI characteristics strongly suggest a benign lesion (a well-defined walled-off lesion without any soft tissue nodularity or invasion into the adjacent soft tissue or bone). We discussed with the patient that due to the lesion's benign MRI appearance, we decided, according to the patient, to perform a single-stage excisional biopsy.

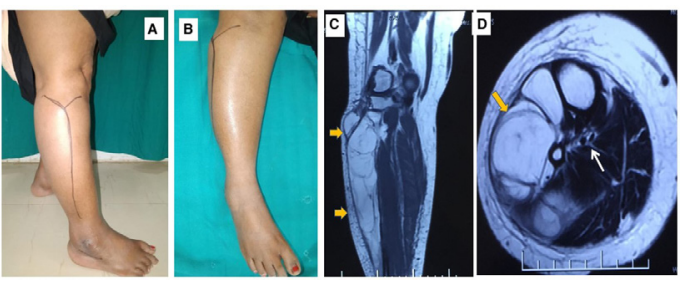

Figure 1 The clinical picture of the patient from side and front (A, B). T1-weighted coronal (C) and axial (D) MRI images show an elongated well-marginated fat signal lesion (yellow arrows). The neurovascular bundle (white arrow in D) is away from the lesion with preserved surrounding fat planes.

Under spinal anaesthesia, through a lateral approach, the entire tumour was delineated and excised (figure 2A,B). Histopathologically, the mass was confirmed to be a fibrolipoma without any signs of malignancy (figure 2C,D). At 6 months, the patient has improved the power of dorsiflexion and evertors (4/5), and there is no evidence of any recurrence.

The WHO has classified benign lipoma into the following groups: classic lipoma, lipomatosis, lipoblastoma or fetal lipoma, spindle cell/pleomorphic lipoma, angiolipoma, angiomyolipoma, hibernoma, myelolipoma and atypical lipoma. ${ }^{11}$ Fibrolipoma are rare variants of lipoma not included in this classification. They contain mature adipose tissue interspersed by dense fibrous connective tissue. ${ }^{1}$ Patients most commonly present in their fifth or sixth decade of life. Their aetiology remains uncertain though mechanical, hormonal and inflammatory influences have been related to their occurrence. ${ }^{12}$

Any part of the body containing fat can develop a fibrolipoma, but they are more commonly seen in the neck, upper extremities and trunk. ${ }^{13}$ ] The lower extremity is a relatively rare location of presentation. $^{7-10}$ These exhibit a smooth, non-tender mass,
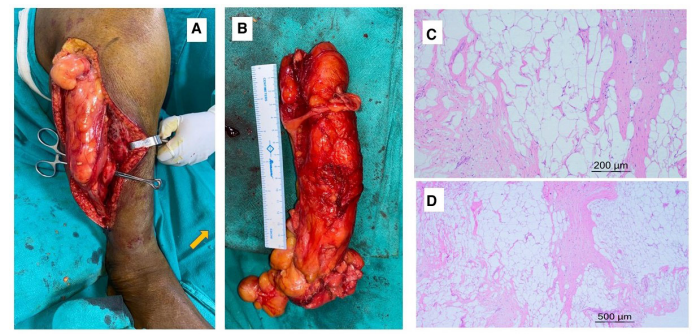

Figure 2 Intraoperative picture of the mass (A); post excision in toto (B); and histopathology (C, D) showing mature adipose tissue and fibrous septa. 
which is insidious and very slowly progressive. When they attain size $>10 \mathrm{~cm}$ or weighing $>1000 \mathrm{~g}$, they are labelled as giant lipomas. ${ }^{7}$ The clinical scenario becomes complicated when there are any morphological variations, as in our case. In the extremity, they can potentially cause compression syndromes. The mass effect of a lipoma is more because of its location than size. The previous cases of giant fibrolipoma in the lower extremity, unlike our case, did not have any compression symptoms. ${ }^{7-10}$

The diagnosis is not usually complex, and ultrasonography may display mature fat tissues embossed within dense fibrous tissues. ${ }^{14}$ When contemplating bony involvement, a CT may be handy. Contrast enhancement can further help to differentiate from liposarcomas, which show increased contrast uptake in the late phase. ${ }^{15}$ MRI will show T1 hyperintense and T2 hypointense mass separated with linear areas of decreased signal intensity. ${ }^{10}$ It is also vital to know about the involvement of vital structures and compartmental breach. Histopathological examination demonstrates abundant collagen bundles embedded in well-differentiated fat tissue. ${ }^{1}$

Giant lipomas need to be differentiated from liposarcomas, malignant fibrous histiocytomas and other benign soft tissue lesions, such as epidermoid cysts, deep haemangiomas and lipoblastomatosis. Exclusion of malignancy should be the primary concern in the diagnosis of giant lipomas. ${ }^{16}$ The patient's age and the onset of symptoms must be earnestly assessed. MRI along with histopathology should be studied to rule out the malignant nature of the tumour.

Marginal surgical excision of the tumour and proper reconstruction of the region should be the treatment modality of choice. ${ }^{1}$ Liposuction is also used as a modality for managing giant lipomas, but must be used judiciously. ${ }^{17}$ In the case of an intramuscular infiltrating fibrolipoma, such as ours, extended resection (sacrificing the structures involved) needs to be considered. There is no recurrence for small mass, but giant fibrolipoma has

\section{Learning points}

- Giant fibrolipoma is rare in the extremity.

- Intramuscular fibrolipoma can cause pressure compartment symptoms.

- Surgery is necessary for treatment and confirmation of the diagnosis in giant fibrolipoma. a higher recurrence rate due to incomplete removal following difficulty in determining the extension. ${ }^{8}$

Contributors SG and MJ operated on the patient. DM did a follow-up and reviewed the literature. SP gave the histopathology pictures. DM and MJ wrote the manuscript where SG and SP gave critical inputs. All authors have read and agree to the content.

Funding The authors have not declared a specific grant for this research from any funding agency in the public, commercial or not-for-profit sectors.

Competing interests None declared.

Patient consent for publication Obtained.

Provenance and peer review Not commissioned; externally peer-reviewed.

ORCID iD

Mantu Jain http://orcid.org/0000-0003-3848-4277

\section{REFERENCES}

1 Balakrishnan C, Nanavati D, Balakrishnan A, et al. Giant lipomas of the upper extremity: case reports and a literature review. Can J Plast Surg 2012;20:40-1.

2 Cribb GL, Cool WP, Ford DJ, et al. Giant lipomatous tumours of the hand and forearm. $J$ Hand Surg Br 2005:30:509-12.

3 Sanchez MR, Golomb FM, Moy JA, et al. Giant lipoma: case report and review of the literature. J Am Acad Dermatol 1993;28:266-8.

4 Fletcher CD, Martin-Bates E. Intramuscular and intermuscular lipoma: neglected diagnoses. Histopathology 1988;12:275-87.

5 Billing V, Mertens F, Domanski HA, et al. Deep-Seated ordinary and atypical lipomas: histopathology, cytogenetics, clinical features, and outcome in 215 tumours of the extremity and trunk wall. J Bone Joint Surg Br 2008;90:929-33.

6 McTighe S, Chernev I. Intramuscular lipoma: a review of the literature. Orthop Rev 2014;6:5618.

7 Zografos GC, Kouerinis I, Kalliopi P, et al. Giant lipoma of the thigh in a patient with morbid obesity. Plast Reconstr Surg 2002;109:1467-8.

8 Pakanati R, Gogineni R, Ede N. Recurrent giant intermuscular lipoma of thigh. J Dr NTR Univ Health Sci 2019:8:219-21.

9 De Werra C, di Filippo G, Tramontano R. Giant lipoma in the thigh a case report. Ann Ital Chir 2016;87:S2239253X16024579.

10 Lui TH. Fibrolipoma of the toe. Foot Ankle Spec 2010;3:33-4.

11 Weiss SW, Sobin LH, Enzinger FM. Lipomatous tumours. In: Histological typing of soft tissue tumours (World Health organization international histological classification of tumours). Pathologists in 9 countries, eds. 23. 2nd ed. Springer-Verlag, 1994.

12 Rao GS, Chatra L, Shenai P. Intra oral Lipoma-A rare entity. Int J Anat Radio/ Surg 2013:2:1-3.

13 Vandeweyer E, Scagnol I. Axillary giant lipoma: a case report. Acta Chir Belg 2005;105:656-7.

14 Whittle C, Cortés M, Baldassare G, et al. [Subgaleal lipomas: ultrasound findings]. Rev Med Chil 2008;136:334-7.

15 Kajihara M, Sugawara Y, Sakayama K, et al. Subcutaneous Fibrolipoma in the back. Radiat Med 2006;24:520-4

16 Zografos GC, Kouerinis I, Kalliopi P, et al. Giant lipoma of the thigh in a patient with morbid obesity. Plast Reconstr Surg 2002;109:1467-8.

17 Pinski KS, Roenigk HH. Liposuction of lipomas. Dermatol Clin 1990;8:483-92.

Copyright 2021 BMJ Publishing Group. All rights reserved. For permission to reuse any of this content visit

https://www.bmj.com/company/products-services/rights-and-licensing/permissions/

BMJ Case Report Fellows may re-use this article for personal use and teaching without any further permission.

Become a Fellow of BMJ Case Reports today and you can:

- Submit as many cases as you like

- Enjoy fast sympathetic peer review and rapid publication of accepted articles

- Access all the published articles

- Re-use any of the published material for personal use and teaching without further permission

Customer Service

If you have any further queries about your subscription, please contact our customer services team on +44 (0) 2071111105 or via email at support@bmj.com.

Visit casereports.bmj.com for more articles like this and to become a Fellow 